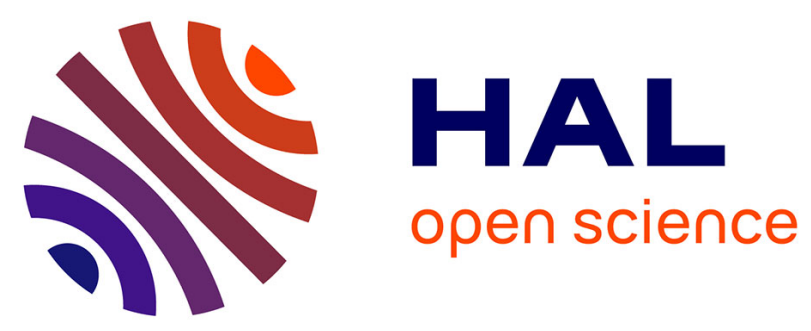

\title{
Document supply and open access: an international survey on grey literature
}

Chérifa Boukacem-Zeghmouri, Joachim Schöpfel

\section{To cite this version:}

Chérifa Boukacem-Zeghmouri, Joachim Schöpfel. Document supply and open access: an international survey on grey literature. Interlending and Document Supply, 2006, 34 (3), pp.96-104. 10.1108/02641610610686012. sic_00181485

\section{HAL Id: sic 00181485 \\ https://archivesic.ccsd.cnrs.fr/sic_00181485}

Submitted on 24 Oct 2007

HAL is a multi-disciplinary open access archive for the deposit and dissemination of scientific research documents, whether they are published or not. The documents may come from teaching and research institutions in France or abroad, or from public or private research centers.
L'archive ouverte pluridisciplinaire HAL, est destinée au dépôt et à la diffusion de documents scientifiques de niveau recherche, publiés ou non, émanant des établissements d'enseignement et de recherche français ou étrangers, des laboratoires publics ou privés.

\section{(c)(1)}

Distributed under a Creative Commons Attribution| 4.0 International License 


\title{
Document supply and open access: an international survey on grey literature
}

Chérifa Boukacem-Zeghmouri

Joachim Schöpfel

\section{Keywords}

Grey literature, scientific and technical information, document supply, open archive initiative (OAI), institutional repositories

\begin{abstract}
Purpose: This article investigates the impact of the open archive initiative on the document supply of grey literature.

Approach: The article is based on a comparative survey of five major institutions: The British Library (UK), the CISTI (Canada), INIST-CNRS (France), the KISTI (South-Korea) and the TIB Hannover (Germany).

Findings: All major document suppliers are more or less deeply involved in the open archive movement, and this involvement has an obvious impact on the policy of acquisition, archiving and supply of grey literature (dissertations, reports, conferences etc.).

Originality: Even if the impact of increased access to digital resources on document supply is relatively well documented, little is known about the specific effect on grey literature, especially in the OA environment. This study provides some evidence concerning this effect.
\end{abstract}

Paper type: research

\section{Introduction}

One characteristic of grey literature is that it is "often difficult to (...) acquire through normal bookselling channels" (British Library) [1] because it lies "outside of commercial circuits of publication and dissemination" (AFNOR) [2]. For those professionals and scientists who wish to gain more information, the search for and acquisition of this kind of "underground literature" can be a time consuming, sometimes expensive and even a frustrating experience, see for example (Hartley 2004) for conference proceedings.

Because of the importance of grey resources for scientific research and teaching, all major public document suppliers invest in collections and delivery services for theses, conference proceedings, reports and unpublished working papers. Some of them offer additional help for the identification and location of these often poorly recorded documents.

These special collections and their bibliographic controls are costly and "grey supply" is often more expensive than the traditional supply of items from "white", commercial publications. 
Today, libraries and document supply services are confronted with the open archive initiative (OAI) movement and have had to adapt to it. The following paper gives an overview of the grey holdings and delivery services of five major document suppliers, and it describes their reactions and projects in the OAI environment.

\section{Some remarks on Open Access and grey literature}

The origins of the short history of open access (OA) are known: free peer-reviewed journals like Harnad's Psycholoquy or Guédon's Surfaces and preprint repositories such as Ginsparg's ArXiv or Harnad's CogPrints have started to challenge the traditional model of scientific communication. These and other initiatives were the scientists' and academics' reaction to the pricing policy implemented by the publishers of journals and reflected their intention to reappropriate the channel of the communication of and to improve the dissemination of research results with the help of the new information and communication technologies (see Crawford et al., 1996). The general impact on intellectual property and the "value chain" has been well documented by (Roosendaal, 2004); its effect on document delivery has already been conceptualised (see Rowse, 2003 or Brown, 2003).

We won't add another review to the rather abundant literature on the theory, history, structure and software of the open access movement. The reader will find comprehensive introductions to the European and more specifically to the French initiatives on the Southampton [3], URFIST Paris [4], CNRS [5] or Max-Planck [6] websites or through textbooks such as (Grüttemeier and Mahon, 2002) and, for the French readers, (Aubry and Janik, 2005).

Yet, the relationship between OA and grey literature is just in its first stages, see for example (Sondergaard et al., 2003), (Banks, 2004) or (Stock and Schöpfel, 2005). Do the "green" or "gold" roads (Guédon, 2004) transform white into grey documents because they leave traditional commercial control and dissemination channels? Or, on the contrary, do open archives promote the shift from grey to white documents by increasing their availability and access? It is obvious that the boundary between white and grey is shifting, and that we need more empirical evidence on grey literature and open access systems in order to update our understanding of what is grey.

Compared to article repositories, open archives for grey literature are more recent and less numerous. One of the first, most important initiatives (if not the first) was the 1996 creation of the Networked Digital Library of Theses and Dissertations (NDLTD) by Virginia Tech. Other totally or partly grey realisations are the French-Canadian Cyberthèses for electronic theses and dissertations (ETD), developed by the Montreal and Lyon 2 universities, Grisemine from the University Lille 1 (Claerebout, 2004), Archimer from the French Research Institute for Exploitation of the Sea (IFREMER), the French national portal in mathematics Mathdoc (preprints, course material, proceedings and ETD together with commercial resources and archives) and the open archives of the CNRS Centre of Direct Scientific Communication at Lyon (CCSD), like ArchiveSIC and MemSIC (publications, dissertations and working papers in information and communication sciences) or TEL (for ETD, see Paillassard et al., 2005).

In spite of their great variety, all these archives and repositories have in common the increased value awarded to grey resources and the improvement of their availability and dissemination. Nevertheless, the majority of them are small scale projects compared to the existing print holdings of grey literature. Up to now, reports, proceedings and other non- 
traditional types of grey literature (educational materials, working papers etc.) have been rather under represented, compared to dissertations and preprints (Banks, 2006).

But what exactly is the impact of the OA movement on the former suppliers of theses, reports and proceedings? How are they reacting in response to the development of institutional repositories; how are they involved especially in the domain of grey literature? There is very little evidence on this topic but for the North American context and the role of the physics preprints archive, ArXiv.org, see (Jackson, 2004), so we decided to undertake an empirical study based on information available on the Web or published elsewhere and on interviews with the leading managers of the cited institutions.

\section{Questions and methodology}

The main questions concerned the existing holdings of grey resources, supply conditions and pricing, involvement in digital and in more specific OA projects, and on approaches and attitudes towards the OA movement. Five major institutions were selected for this study:

The British Library (BL) [7]

The Canadian Institute of Scientific and Technical Information (CISTI) [8]

The French Institut de l'Information Scientifique et Technique (INIST) [9]

The Korean Institute of Scientific and Technical Information (KISTI) [10]

The German National Library of Science and Technology of the University of Hannover (TIB) [11]

These "traditional suppliers" have in common a public mission to collect, preserve, archive and disseminate scientific information through a non-profit ILL and document supply service that is based on a mixed economic model with their income supplied both by public funding and their customers' fees. In a certain way, they all share the "belief that collecting world knowledge and making it available for investigation generates new ideas and advances society" (The British Library, 2005).

ILL and document supply networks such as Subito, IMPALA or AutoDoc, were excluded because they have neither their own holdings nor a specific acquisition policy. For similar reasons, we excluded corporate, profit-based suppliers such as Infotrieve.

First, we gathered information about collections and supply conditions - services, prices, activity reports etc. - from web sites or from other sources. Based on this information, we contacted the leading supply managers of the five institutions and proposed a semi-directive, oral or written survey on the following topics:

1. Figures on their grey document supply and ILL in 2004.

2. Comparison of these figures to the overall supply and ILL (\%).

3. The recent evolution compared to previous years.

4. Their projects in the area of grey literature.

5. Their OA projects.

6. The impact on the collection of grey literature.

7. The impact on document supply (service offer, pricing).

8. The impact on the bibliographic control of grey literature (cataloguing, record data).

9. The impact on the information system. 
Data synthesis and interpretation were communicated to the institutions for comments and validation. Our underlying hypotheses are:

- The part of grey literature in overall supply activity is rather small.

- The "grey supply" follows the general trends of the overall supply.

- Due to their public mission, all institutions are strongly interested and more and more involved in open access projects.

- One part of these OA projects is related to traditional grey literature.

- This increased involvement has or will have various effects on the way they function and their activities, especially on the development of collections and supply services.

- This involvement may also impact bibliographic control and the information system.

In the following, we first of all present the results of the survey (case studies) and then, in the conclusion, test the underlying hypotheses.

\section{The British Library}

The British Library is the world's largest supplier of scientific information (Brindley, 2005). Its grey holdings - mainly dissertations, reports and conference proceedings - comprise about 4.9 million items from a wide variety of sources (UK theses, NASA and NTIS reports, proceedings from most of the international scientific events, but also maps, manuscripts, audio and music documents, etc.) [12] The British Library was the most important national input centre in the European EAGLE network, providing more than $50 \%$ of the overall SIGLE records (for more information, see (Tillett and Newbold, 2006)).

Grey document supply and ILL in 2003: The BLDSC received over 110,000 requests for grey literature in 2003. The satisfaction rate for supplying grey literature is approximately $85 \%$. Through their experience they have found, unsurprisingly, that the satisfaction rate for requests increases when they improve access through cataloguing and indexing.

Comparison with the overall supply: This represents $5 \%$ of the total items supplied that year (2003).

Evolution: Since 1998/1999 the British Library has experienced a significant decrease in the number of requests. Even if the exact number of requests is no longer published in the annual reports, the decline can be estimated at $10 \%$ per year. Although much of their grey literature holdings have been produced in "user unfriendly" formats (e.g. microform) or on paper, they are able to supply this material electronically to their customers using their Secure Electronic Delivery (SED) system. This means that grey literature can be converted into a format that users require, i.e. a secure PDF, delivered directly to the desktop.

Projects in the area of grey literature and OA projects: The British Library contributes to OA projects mainly through the Research Support Libraries Programme (RSLP), which indicates improved relationships with the UK higher education community (Law, 2004, Ceeney, 2004); one pilot project was the MAGiC cooperation with Cranfield University on scientific and technical reports (Needham, 2002). The British Library is working with higher education institutions on the "Electronic Theses Online Service" (ETHoS) [13], to develop an infrastructure to enable full text electronic access for researchers. In addition to UK theses 
they also hold more than 475,000 North American doctoral theses that were collected up until September 2001. Other projects at the edge of grey and OA are the selective archiving of websites, the archival sound recordings project and the digitisation of selected collections in the context of the UK Digital Preservation Coalition (Millar, 2001). Some "Co-operation and Partnership Programmes" (Smith, 2001) are focused on the preserving, digitisation and display of national heritage resources and non traditional items, for example, legal materials, company reports, official publications etc.

The impact on the collection of grey literature: Over the years the British Library, through the BLDSC has made considerable efforts to identify producers of material, develop collections and holdings and, more importantly, develop mechanisms in order to make the material accessible through remote supply. For example most British reports are listed on the BL OPAC to enable the easy search for and organisation of this important research resource. The decrease in revenue from document supply does not affect its acquisition policy "which (is) seen as part of the public good" (Brown, 2003). The fundamental role of information collecting and preserving has been validated and reinforced by the report "Redefining the Library: The British Library's strategy 2005-2008" [14] that places the end user at the heart of its overall considerations. Their central credo is to "enrich the user's experience"; their main objective: the creation of a digital library. In this new environment, document supply is no longer a "stand alone business" or "separate entity" but "one part of an integrated range of information services" (Brindley, 2005).

The impact on document supply: The British Library is working in a consortium of six institutions, called the UK Web Archiving Consortium [15], which is looking at the practicalities of archiving websites and content based on a selective permissions based approach. The British Library is also developing a digital preservation system in order to ensure the long- term preservation of and access to electronically published material.

The impact on the bibliographic control of grey literature: Whilst the British Library aims to make its grey literature collections visible to users, like many other libraries they too are "guilty" of not cataloguing all the material. This is especially true of their US reports series. They do catalogue the British reports, but the numbers of reports distributed by overseas agencies make their holding so substantial that they have not created records for them. They have relied on the finding aids (indexes, databases, announcements and bulletins) available from the agencies themselves (e.g. NTIS or ERIC databases) to match requests against their holdings.

The impact on the information system: No information.

Acknowledgments to Samantha Tillett for providing data and information on document supply and open access to grey literature.

\section{CISTI}

CISTI has a long history going back to 1929 (Krym and VanBuskirk, 2001). As one of the largest collections in North America, its mission is "To advance research and innovation through high-value information and publishing services in science, technology, and medicine" [16] CISTI has become, over the years, the major provider of scientific information in Canada, making up about $36 \%$ of the Canadian market in the year 2000. 
Apart from scientific periodicals (50,000+ titles), the CISTI collection includes monographs, conference proceedings and technical reports [17].

Grey document supply in 2004: In 2004 the Canadian supplier received 62,054 requests for grey literature shared between requests for conferences proceedings $(59,500$ requests, $96 \%)$ and those for technical reports, including those written by CNRC researchers $(2,554$ requests, $4 \%)$.

Comparison of these figures to the overall supply: Requests for grey literature in 2004 account for $9 \%$ of the total number of requests registered at CISTI.

Evolution: Since 2002, CISTI has reported a decrease in the overall volume of document supply requests for traditional journal articles, which is linked to the impact of the "big deals", the availability of free resources on the Web, and open (free) journals and archives. This decrease in traditional document supply, considered to be a long lasting reality, is one of the factors that were taken into consideration in the development of CISTI's strategic plan for 2005-2010 [18]. The figures provided make it possible to see that the portion of grey literature demand is growing. The number of requests has increased from $7 \%$ of the total demand for 2003 to $9 \%$ in 2004. Moreover, this evolution was confirmed in 2005 with close to $10 \%$ of the total recorded number of requests being for grey literature.

Their projects in the area of grey literature and OA: There are currently no active projects in the areas of grey literature. However, one proposed grey literature project would result in the creation of a full text database of materials published by the various Institutes of the National Research Council Canada. Other projects related to grey literature could be considered within the framework of the Strategic plan for 2005 - 2010 [19] which includes the establishment of "collaborative agreements, partnerships, systems and practices required to carry out all stages of providing STM information online". This integrated, partnershipbased approach to STM information will result in a Canadian science "infostructure" and a viable national STM publishing infrastructure. The competitive advantages offered by this investment will lead to better research and a more innovative economy" [20]

In the area of Open Access, CISTI's Research Press makes online version of its 15 peerreviewed journals available to the Canadian scientific community for free through the Canadian Depository Services Program (DSP) and through the CISTI web site. The "depository services program" (DSP) is designed "to ensure that Canadians have ready and equal access to federal government information", made possible by funding from the Treasury Board of Canada (VanBuskirk and Krym, 2003).

CISTI's overall position seems rather prudent - based on a realistic knowledge of the information requirements of its customers, CISTI acknowledges that the number of supply requests may continue to decrease but that this is mainly linked to the online access of electronic periodicals and not to the development of institutional repositories or other open archives.

The impact on the collection of grey literature: The availability of grey literature on the Web does not seem to have affected CISTI activities. On the contrary, an intensification of their work in conjunction with other institutions has been announced, particularly at the 
American level, with traditional partners such as OCLC, or more specifically with the ICSTI (International Council for Scientific and Technical Information) [21]. They are engaged in work with European partners as well, such as INIST, with which agreements for the diffusion of documents have been established.

The impact on document supply: Similar factors as described in the paragraph above.

The impact on the bibliographic control of grey literature: For the moment, technical reports proposed for supply do not have subject headings, moreover the cataloguing which has been done is incomplete, including that provided for their collection of microfiche. However keyword searching makes them readily accessible Thus, in order to improve bibliographical control, the Canadian supplier is focusing on the completion of work in these specific areas, particularly the indexing of reports. A significant factor, however, affecting the demand for technical reports may be that these materials are not well covered by standard abstracting and indexing services.

The impact on the information system: The principal repercussions perceived by the Canadian supplier relate to the question of the validation of the documents proposed within the framework of a service supplying grey literature. The credibility of the proposed services is dependent on the quality of the documents. This question of the validation of documents and thus of credibility is what is mostly at stake and poses the central problem, but how can it be defined? In the end, the main difficulty lies in discerning the difference in quality between documents that have not passed the traditional validation process.

Acknowledgments to Marsha Kaisermann for providing data and information on document supply and open access to grey literature.

\section{INIST}

Founded in 1988, the Institute for Scientific and Technical Information is a service unit of the French National Centre for Scientific Research (CNRS). Its mission is to collect, analyse and disseminate the results and findings of worldwide research in STM, social sciences and humanities. The supply of copies of scientific and technical documents is part of its traditional activities, whether or not the documents are held at the INIST (Schöpfel, 2003).

The legal background to this service is based on the French law on intellectual property as well as on an agreement with the French copyright agency (CFC).

The INIST grey collections are rather significant: 70,000 conference proceedings, 150,000 dissertations and theses and 70,000 scientific and technical reports. As the national centre of the European EAGLE network, INIST is a central part in the French landscape of the collection and dissemination of grey public research documents.

Grey document supply in 2004: INIST received 15,623 requests for grey items (87\% conference proceedings, $7 \%$ dissertations, $6 \%$ reports). Only a small part (14\%) was delivered from INIST's own holdings, the rest was supplied through the INIST back-up network. The satisfaction rate was $92 \%$. All items were delivered as print copies or through ARIEL with no supply of returnables. $40 \%$ of the grey items were requested by corporate (for-profit) customers. 
Comparison with the overall supply: The supply of grey literature represented only $3 \%$ of the overall activity.

Evolution: The general evolution of INIST supply activity is well documented (see Schöpfel, 2003, Boukacem et al., to be published). Since 2001, the downward trend is about $10 \%$ per year. With a decrease of 35\% between 2001 and 2005, the figures for grey literature supply match the general evolution (37\%). Nevertheless, the decline of the major types of grey literature is disparate, being more significant for dissertations (44\%) and conference proceedings $(35 \%)$ than for reports $(21 \%)$.

Projects in the area of grey literature: INIST currently has five major projects in the area of grey literature. Two are meant to improve the bibliographic control and visibility of its grey holdings: the cataloguing of 14,000 recent French STM dissertations and the digitisation and indexing of 40,000 CNRS reports published principally between 1970 and 1990. The third project is to integrate the Proquest-UMI database of mostly American dissertations in the service offering of INIST, in order to improve access to these documents and to increase their use in France. The fourth project is the participation in the Grey Literature International Steering Committee (GLISC, also called "Nancy Group") [22], which publishes guidelines for the presentation of scientific and technical reports. The final project is a partnership with the French start-up Droit in Situ [23] that focuses on the indexing of the multimedia material used in scientific conferences.

OA projects: CNRS and INIST have been particularly active in several ways in the European and French OA movement (Romary, 2005), (Schöpfel, 2005), (Grüttemeier, 2006). Some of these activities include:

- The signing of the Berlin Declaration on Open Access in 2003.

- Institutional Membership of BiomedCentral (French host of the BMC archives).

- Contribution to a national common OA policy and the development of a central national repository for French public research, together with other public research organisations (INSERM, INRIA, INRA).

- The development of OA platforms for digital periodicals [24] and reports based on the MIT DSpace software.

- The organization of conferences and seminars on open access to scientific information and the creation of a Web site dedicated to OA issues with international news, reference texts and review articles [25].

Three OA projects are directly related to grey literature:

- The development of an OA platform "LARA" (Libre Accès aux Rapports) for scientific reports based on the MIT DSpace software (Stock et al., 2006). This project includes the retro-digitisation of print reports and the possibility of an online deposit of digital material by the organisations that produce it (laboratories, research centres, ministries).

- The transformation of the former SIGLE database, together with the operating agent of EAGLE, FIZ-Karlsruhe, into an open archive of bibliographic records of European grey literature (OpenSIGLE).

- The archiving of French conferences in an OAI environment, for instance seminars from the Observatory for Micro and Nanotechnologies. 
Another project is only at the first stage: the development of a specific search engine for European grey resources (databases, catalogues, open archives). Today, it is uncertain in which way this project could be made reality (Schöpfel, 2006).

The impact on the collection of grey literature: Document supply and resource acquisition are not directly linked. INIST's purpose is to supply all requested documents, whether they are part of its collections or not. In 2005, more than $20 \%$ of the items supplied were from other (French and foreign) libraries, and this percentage is steadily increasing. At the heart of the supply service is the identification and location of the requested items. As a result, the INIST supply service could become more and more independent of its own collections that would be "replaced" by remote resources (online resources, holdings from other libraries). The number of collected grey documents is steadily decreasing annually.

The impact on document supply: INIST offers print and electronic delivery (ARIEL); secure electronic delivery with digital rights management is under preparation. From 2004 INIST has been experimenting with the supply of URLs of freely accessible online resources. In reaction to its customers' needs, INIST is in the process of setting up a partnership with Proquest-UMI and is developing more open access to grey resources (theses, reports).

The impact on the bibliographic control of grey literature: The overall tendency is characterised by four aspects: the increased outsourcing of record production, the cataloguing of up to now "invisible" collections (dissertations, reports), the creation of metadata (reports, conferences) and metadata harvesting (theses). Compared with the past with its comprehensive UNIMARC records, this tendency will generate increased visibility but also a decrease in the bibliographic control of grey literature. At the same time, INIST is involved in the standardization of metadata (Nancy is the European Support of the Text Encoding Initiative TEI) that may in the future impact - and improve - the bibliographic control of grey documents.

The impact on the information system: There is a significant shift from a highly integrated system to a more open architecture, based on the cohabitation of a traditional library system and workflow and OA software. The backbone of this emerging information system is a large XML data repository with nearly $20 \mathrm{~m}$ records from different origins and sources, with a specific format for interoperability (DTD "Exodic") combined with an online search engine for bibliographic and metadata.

Acknowledgments to Hélène Prost for providing statistical data on the document supply of grey literature.

\section{KISTI}

The South Korean science and technology information centre, a non-profit affiliated organization of the Korean Research Council of Public Science and Technology under the control of the Prime Minister's Office (Choi, 2003), provides a nationwide information service to support industrial and technological development in Korea by facilitating the access to and utilization of information resources. 
The KISTI collection contains a wide variety of resources, journals, monographs, R\&D reports, conference proceedings, patent specifications etc. KISTI has developed a Scientific Information Integrated System (SIIS), a portal system that gives access to databases and online resources. [26] Grey literature is part of these digital information resources: access is provided to research and development reports (200,000 items), master and doctoral dissertations (700,000 items), Korean patents (2,100,000 items) and foreign patents $(14,000,000$ items), the science and technology factual database (1,400,000 items) and scientific materials and instruments (22,000 items) (Choi, 2003).

Document supply: The document supply service supplied more than 300,000 items in 2001, from the KISTI holdings or from other libraries (11\%), especially foreign document service bodies such as the British Library (Shin and Oh, 2002). There are no figures concerning grey documents or the evolution in their supply.

OA and GL projects: The OAI is discussed in Korea but up to now it seems unclear if it would become a national standard for the long-term preserving of and access to digital information (Choi 2003). Nevertheless, KISTI has been developing a multilingual electronic theses and dissertations (ETD) system since 1989 as a national digital library in South Korea and as part of the international effort to construct a digital library network of theses and dissertations (Zhang, Lee and You, 2001). This database supports full-text searches in English, Korean, Chinese and Japanese, and provides access at individual page level. In September 2001, it already contained 23,368 ETDs; about $25 \%$ of the visits came from more than 20 foreign countries.

Impact on collection, supply, bibliographic control or system: No information.

\section{TIB Hannover}

As one of the most important libraries in Germany since its foundation in 1959, the German National Library of Science and Technology of the University of Hannover (TIB) defines its task as the following: "to comprehensively acquire and archive literature from around the world pertaining to engineering and the natural sciences... Holdings (...) are available (...) through our document delivery service". [27] The library "places a particular emphasis" on the acquisition of grey literature. The TIB holdings comprise around 8.2 million items (print, microforms, CD-ROMs), a figure that includes conference proceedings, research reports, patents, standards and dissertations.

Grey document supply in 2005: The TIB received about 133,000 orders for grey literature, of which $90 \%$ were for scientific and technical reports from its own holdings.

Comparison with the overall supply: The supply of grey documents represented $27 \%$ of the overall activity (492,000 requests in 2005). About $90 \%$ of all items were supplied in a digital format (e-mail, FTP).

Evolution: The overall document supply increased significantly between 2001 and 2005 (+ $15 \%)$. While the supply of returnables decreased $(-8 \%)$, the delivery of print or digital copies increased considerably $(+23 \%)$. 
OA and GL projects: The TIB participates in a large number of projects, with a key focus on electronic publications and the development of a digital library. Some current projects are on grey literature and/or open access: [28]

- CODATA: contribution to the publication and citation of scientific primary data through attribution of DOI/URNs [29].

- ELAN Niedersachsen: development of e-learning services (metadata model, content integration into online access systems, cross-linking with standard services, and long term preservation in an OA environment).

- Probado: development of a service (preservation, handling, search, delivery) for complex, non-textual data and documents (e-learning, music, 3-dimensional computer graphics).

The TIB is deeply involved in the development and content acquisition of the German VASCODA portal for scientific information [30], based on the co-operation of 33 German institutions.

The impact on the collection of grey literature: The TIB tries to collect all significant publications in its scientific domains (sciences and technology), at least those published in the most important languages. This objective also applies to grey literature. As these documents are more and more often only available in a digital format, the TIB tries to get authorization from the copyright-owners to download these files on a local server and, if possible, to archive a print copy. For all the projects funded by the Federal Ministry of Research, the TIB is the deposit library of the (digital) project reports, and these reports are freely available online through the service TIBORDER.

The impact on document supply: The main impact on traditional document supply (mail, fax, e-mail, FTP) does not come from OA but from the evolution of the legal environment (new German law on intellectual property). In 2006 the TIB will implement a Digital Rights Management (DRM) system (FileOpen software).

The impact on the bibliographic control of grey literature: No special impact has been noted resulting from OA developments. The TIB continues to import metadata from online databases into the TIB portal and to link them to the full-text versions (GetInfo-project with FIZ Chemie, FIZ Technik and FIZ Karlsruhe). Additionally, the TIB acquires bibliographic data from the British Library (Inside Serials and Conferences) and imports other metadata through specific co-operations, as for example with the CERN or the Fraunhofer institutes.

The impact on the information system: The TIB maintains its ILS system (PICA) for "traditional" library activity but is developing, together with the FIZ Technik, a completely new IT system that will be able to archive, index and provide online access to several million full-text documents, including Customer Relationship Management (CRM) software functionalities. In 2007, the TIB will launch a new user interface with the "Lucene" search engine technology.

Acknowledgments to Uwe Rosemann for providing data and information on the document supply and open access to grey literature. 


\section{Concluding remarks}

The following conclusions are based on an analysis of web-based and published information, amended and completed by the feedback on our survey on document supply and OA projects. They are presented along with the six underlying hypotheses.

(1) The part of grey literature in overall document supply activity is rather small. All libraries place special emphasis on grey literature and have important grey collections, especially of conference proceedings, technical reports and dissertations. Nevertheless, the relative part of grey document supply differs between these suppliers:

\begin{tabular}{|l|c|l|}
\hline Institution & \% of grey supply & Main type of document \\
\hline INIST & $3 \%$ & Conferences \\
\hline British Library & $5 \%$ & n.d. \\
\hline CISTI & $10 \%$ & Conferences \\
\hline TIB Hannover & $27 \%$ & Reports \\
\hline KISTI & n.d. & n.d. \\
\hline
\end{tabular}

Table 1: \% of grey document supply, compared to overall activity

We can distinguish two groups, INIST and the British Library with a grey document supply up to 5\%, and the CISTI and TIB Hannover with a more important part (>10\%). According to these figures, our underlying hypothesis has to be amended.

(2) The "grey supply" follows the general trends of the overall supply. The reported data seem to validate our assumption, even if the trend is different between INIST (downward trend) and CISTI and TIB where grey supply tends to increase. This tendency marks the growing importance of grey literature in the document landscape and of its visibility to users. In fact, this report is closely akin to the remarks made by (Banks, 2005).

(3) Due to their public mission, all institutions are strongly interested and more and more involved in open access projects. The given information validates our hypothesis. All the same, the specific involvement depends on the integration in the (national) information market and institutional environment (higher education, research communities) but also in financial and human resources.

(4) One part of these OA projects is related to traditional grey literature. The analysis confirms our assumption. However, each institution presents specific characteristics:

\begin{tabular}{|c|c|c|c|c|}
\hline Institution & Theses & Conferences & Reports & Others \\
\hline INIST & & OA & $\mathrm{OA}$ & $\begin{array}{l}\text { OpenSIGLE, NR for } \\
\text { publications }\end{array}$ \\
\hline British Library & $\mathrm{NR}$ & & $\mathrm{OA}$ & $\begin{array}{l}\text { National heritage, non-traditiona } \\
\text { items }\end{array}$ \\
\hline CISTI & & & & NR for CNRC publications \\
\hline TIB Hannover & & & NR & $\begin{array}{l}\text { Primary data, courseware, non- } \\
\text { textual material }\end{array}$ \\
\hline KISTI & NR & & & \\
\hline
\end{tabular}

Table 2: OA projects (NR: national repository, OA: open archive) 
Two comments maybe made: Up to now, little attention seems to be paid to open access and conference proceedings. Additionally, open archives or repositories of non-traditional items (primary data etc.) are only now beginning to gain some importance.

(5) This increased involvement has or will have various effects on the way they function and their activities, especially on the development of collections and supply services. Following our information, it seems too early to validate or invalidate this assumption. Up to now, one can observe only little impact of OA on the traditional activities. This may change in the future.

(6) This involvement may also impact bibliographic control and the information system. Same conclusion. Few changes were noted in the information systems on which the supply of grey literature is based, or in the bibliographic control. We can't validate this hypothesis up to now.

The answers collected show the very great diversity between the situations of document suppliers vis-à-vis a topical issue which directly concerns them. The nuances which one can note, regarding their lines of thought or their projects nevertheless display a commitment to a more comprehensive policy of access to scientific information. Access to grey literature in an electronic context has greater economic potential than in the traditional paper era. We can thus put forward the idea that the commitment of the document suppliers in the domain of OA to the dissemination of grey literature is a strategic means of establishing their position in the broader scientific and technical information market.

Perhaps an update of this survey in one or two years could provide more evidence on the relationship between the OA movement, document supply and grey literature. It would be interesting, too, to compare our data with those from other institutions, networks and commercial suppliers in order to gain deeper insight in the moving information market.

\section{Bibliography}

Aubry, C. and Janik, J. (2005), Les archives ouvertes: Enjeux et pratiques. ADBS, Paris.

Boukacem-Zeghmouri, C., Bador, P., Lafouge, T., Prost, H. and Schöpfel, J. (forthcoming), "Analysis of the downward trend in document delivery in pharmaceutics: a case study from INIST in France". Interlending \& Document Supply.

Banks, M. (2004), "Connections between open access publishing and access to grey literature". Journal of the Medical Library Association, Vol 92, No 2, pp. 164-166.

Banks, M. (2006), "Towards a Continuum of Scholarship: The eventual Collapse of the Distinction between Grey and non-Grey Literature?", in Farace, D. and Frantzen, J. (Ed.), GL7 Conference Proceedings. Seventh International Conference on Grey Literature: Open Access to Grey Resources. Nancy, 5-6 December 2005. TextRelease, Amsterdam.

Brindley, L. (2005), "The British Library: its origins, development and future". Interlending \& Document Supply, Vol 33, No 2, pp. 76-80.

The British Library (2005), 32 ${ }^{\text {nd }}$ Annual Report and Accounts 2004/2005. The Stationary Office, London.

Brown, D. (2003), "Is this the end of the 'article economy'? A strategic review of document delivery”. Interlending \& Document Supply, Vol 31, No 4, pp. 253-263. 
Ceeney, N. (2004), "The British Library - delivering the world's knowledge: some recent developments". Interlending \& Document Supply, Vol 32, No 4, pp. 234-238.

Choi, W. (2003), "The Development of Digital Libraries in South Korea". Libri, Vol 53, pp. 130-141.

Claerebout, M.F. (2004), "Grisemine, a digital library of grey university literature", in Farace, D. and Frantzen, J. (Ed.), GL5 Conference Proceedings. Fifth International Conference on Grey Literature: Grey Matters in the World of Networked Information. Amsterdam, 4-5 December 2003. TextRelease, Amsterdam, pp. 27-31.

Crawford, S. Y., Hurd, J. M. and Weller, A. C. (1996), From print to electronic: the transformation of scientific communication. Silver Spring, ASIS Monograph Series.

Grüttemeier, H. (2006), "The Way to Open Access - French Strategies to Move Forward". Tushu Qingbao Gongzuo (Library and Information Service), Vol 50, No 1, pp. 27-33.

Grüttemeier, H. and Mahon, B. (2003), Open Access to Scientific and Technical Information. State of Art and Future Trends. ICSTI/INIST/INSERM Seminar, 23-24 January 2003, Paris, France. IOS Press, Amsterdam.

Guédon, J.C. (2004), “The 'green' and 'gold' roads to Open Access: the case for mixing and matching”. Serials Review, Vol 30, No 4, pp. 315-328.

Hartley, J. (2004), “On requesting conference papers electronically”. Journal of Information Science, Vol 30, No 5, pp. 475-479.

Jackson, M.E. (2004), "Document access in the United States: revisited 1978-2004". Interlending \& Document Supply, Vol 32, No 3, pp. 164-168.

Krym, N. and VanBuskirk, M. (2001), "Resource-sharing roles and responsibilities for CISTI: change is the constant”. Interlending \& Document Supply, Vol 29, No 1, pp. 11-16.

Law, D. (2004), "Tilting at windmills: BLDSC and the UK higher education community". Interlending \& Document Supply, Vol 32, No 2, pp. 85-89.

Millar, I. (2001), "Nouvelles orientations pour la British Library". Bulletin des Bibliothèques de France, Vol 46, No 6, pp. 86-92.

Molgat, L. (2005), "Transforming Document Delivery in the e-Content Environment". World Library and Information Congress: $71^{\text {th }}$ IFLA General Conference and Council. August $14^{\text {th }}-18^{\text {th }} 2005$, Oslo, Norway.

Needham, P. (2002), "MAGiC: Shining a new light on a grey area". Serials, Vol 15, No 3, pp. 201-206.

Paillassard, P., Schöpfel, J. and Stock, C. (2005), "How to get a French doctoral thesis, especially when you aren't French". Publishing Research Quarterly, Vol 21, No 1, pp. 73 93.

Pintat, R. (2003), “Archives ouvertes: une alternative à la subordination des bibliothécaires aux éditeurs numériques?" Bulletin des Bibliothèques de France, Vol 48, No 2, pp. 90- 94.

Romary, L. (2005), "The way to open resources". Berlin 3 Open Access: Progress in Implementing the Berlin Declaration on Open Access to Knowledge in the Sciences and Humanities, University of Southampton, Southampton, 28 February-1 March, available at: http://www.eprints.org/berlin3/

Roosendaal, H. E. (2004), "Driving change in the research and HE information market". Learned Publishing, Vol 17, No 1, pp. 1-6.

Rowse, M. (2003), "Individual article supply: some strategic directions". Interlending \& Document Supply, Vol 31, No 2, pp. 86-93.

Schöpfel, J. (2003), "INIST-CNRS in France: 'a model of efficiency"”. Interlending \& Document Supply, Vol 31, No 2, pp. 94-103.

Schöpfel, J. (2005), "Between open access and copyright: document supply in France". Interlending \& Document Supply, Vol 33, No 3, pp. 158-161. 
Schöpfel, J.: "MetaGrey Europe, A Proposal in the Aftermath of EAGLE-SIGLE". Farace, D. \& Frantzen, J. (ed.) : GL7 Conference Proceedings. Seventh International Conference on Grey Literature: Open Access to Grey Resources. Nancy, 5-6 December 2005. Amsterdam: TextRelease 2006.

Shin, E.J. and Oh, K.M. (2002), "Interlending and document supply developments in South Korea". Interlending \& Document Supply, Vol 30, No 3, pp. 136-138.

Smith, G. (2001), "Document delivery as an aspect of co-operation: the British Library's Cooperation and Partnership Programme". Interlending \& Document Supply, Vol 29, No 3, pp. 114-119.

Stock C. and Schöpfel J. (2004), "Grey Literature in an Open Context: From Certainty to New Challenges", in Farace, D. and Frantzen, J. (Ed.), GL5 Conference Proceedings. Fifth International Conference on Grey Literature: Grey Matters in the World of Networked Information. Amsterdam, 4-5 December 2003. TextRelease, Amsterdam, pp. 199-202.

Stock, C., Rocklin, E. and Cordier, A. (2006), "LARA - open access to scientific and technical reports". Farace, D. and Frantzen, J. (Ed.), GL7 Conference Proceedings. Seventh International Conference on Grey Literature: Open Access to Grey Resources. Nancy, 5-6 December 2005. TextRelease, Amsterdam.

Sondergaard, T. F., Andersen, J. and Hjorland, B. (2003), "Documents and the communication of scientific and scholarly information. Revising and updating the UNISIST model". Journal of Documentation, Vol 59, No 3, pp. 278-320.

Tillett, S. and Newbold, E. (2006), "Grey literature at The British Library - revealing a hidden resource”. Interlending \& Document Supply, Vol 34, No 2, pp 70-73.

VanBuskirk, M. and Krym, N. (2003), "Resource-sharing roles and responsibilities for CISTI: for better or for ILL?” Interlending \& Document Supply, Vol 31, No 3, pp. 169-173.

Zhang, Y., Lee, K. and You, B.J. (2001), "Usage patterns of an electronic theses and dissertations system". Online Information Review, Vol 25, No 6, pp. 370-378.

Web references

[1] http://www.bl.uk/

[2] http://www.afnor.fr/portail.asp

[3] http://www.eprint.org

[4] http://www.ccr.jussieu.fr/urfist/ArchiveOuverte/OA.html\#ou

[5] http://openaccess.inist.fr

[6] http://www.zim.mpg.de

[7] http://www.bl.uk.com

[8] http://icist.cnrc.gc.ca

[9] http://icist.cnrc.gc.ca

[10] http://www. kisti.re.kr

[11] http://www.tib.uni-hannover.de/

[12] http://www.bl.uk/services/document/dsc.html

[13] http://www.ethos.ac.uk/

[14] http://www.bl.uk/about/strategy.html

[15] http://www.webarchive.org.uk/

[16] http://cisti-icist.nrc-cnrc.gc.ca/about/stratplan_2_e.html

[17] http://cisti-icist.nrc-cnrc.gc.ca/irm/statist_e.html

[18] http://cisti-icist.nrc-cnrc.gc.ca/irm/statist_e.html

[19] idem

[20] http://cisti-icist.nrc-cnrc.gc.ca/about/stratplan_summary_e.html

[21] http://www.icsti.org/ 
[22] http://www.glisc.info

[23] http://www.droit-in-situ.net

[24] http://irevues.inist.fr

[25] http://www.inist.fr/openaccess

[26] http://science.knowledge.go.kr

[27] http://www.tib-hannover.de/en/about_us/overview

[28] http://www.tib-hannover.de/en/about_us/projects/?p=on

[29] Uniform Resource Name, a Uniform Resource Identifier (URI) that uses the urn scheme and does not imply availability of the identified resource (http://en.wikipedia.org/wiki/URN [30] http://www.vascoda.de

All web sites visited between November 2005 and April 2006.

This article is a revised and augmented version of our communication "Access and Document Supply: A Comparative Study of Grey Literature" presented at GL7 Seventh International Conference on Grey Literature: Open Access to Grey Resources. Nancy, 5-6 December 2005. Acknowledgments to Naomi R. Hull for a careful review of the English version.

\section{The authors}

Chérifa Boukacem-Zeghmouri is Lecturer at the Department of Information and Communication Sciences at the University of Lille 3.

boukacemc@yahoo.fr

Joachim Schöpfel is Head of the E-publishing and Document Supply Department at INISTCNRS and Lecturer on Scientific Information at the University of Nancy.

schopfel@inist.fr 